\title{
DETERMINAN PSIKOLOGIS IBU RUMAH TANGGA DENGAN HIV (+) DI PROVINSI KALIMANTAN TENGAH
}

\section{Psychological Determinants of Households Living With HIV (+) in Central Kalimantan Province}

\author{
1*Nurhalina, ${ }^{2}$ Nurul Chusna, \& ${ }^{3}$ Srie Rosmilawati \\ ${ }^{1}$ Department of Medical Laboratory Technology, Universitas Muhammadiyah Palangkaraya, Jl. RTA. Milono Km. 1,5, Palangka Raya, \\ Indonesia \\ ${ }^{2}$ Department of Pharmacy, Universitas Muhammadiyah Palangkaraya, Jl. RTA. Milono Km. 1,5, Palangka Raya, Indonesia \\ ${ }^{3}$ Department of Communication Science, Universitas Muhammadiyah Palangkaraya, Jl. RTA. Milono Km. 1,5, Palangka Raya, Indonesia
}

*e-mail : nurhalina@umpalangkaraya.ac.id

\begin{abstract}
ABSTRAK
Ibu rumah tangga dengan HIV/ AIDS merupakan trend baru dalam epidemi HIV di Indonesia. Secara keseluruhan penularan heteroseksual menjadi moda penularan utama yang mendominasi temuan kasus baru (69.6\%)sampai dengan kuartal ke pertama tahun 2017, Di Provinsi Kalimantan Tengah dilaporkan jumlah kumulatif HIV/AIDS mencapai 810 kasus, dimana ibu rumah tangga (19.4\%) merupakan kelompok tertinggi setelah kelompok swasta. Tujuan penelitian ini adalah melihat determinan psikologis ibu rumah tangga dengan HIV (+) di Provinsi Kalimantan Tengah. Metode penelitian ini adalah observational analitik dengan pendekatan potong lintang (cross sectional study). Populasi adalah penderita yang berkunjung di RSUD dr. Sylvanus Palangka Raya, RSUD dr. Murjani Sampit, RSUD Sultan Immanudin Pangkalanbun dan RSUD dr.H Soemarno S Kuala Kapuas. Sample dieklusi apabila mengalami gangguan kejiwaan dan sakratul maut. Hasil penelitian menunjukan bahwa variabel sosiodemografi seperti usia, riwayat perkawinan, suku, tingkat pendidikan, status pekerjaan,jumlah anak, lama didiagnosa dan fase HIV bukan merupakan determinan psikologis responden ( $\mathrm{p}>0.05)$.
\end{abstract}

Kata kunci : HIV AIDS, ODHA, Kualitas Psikologi

\section{ABSTRACT}

Housewives living with HIV AIDS are a new trend in the HIV epidemic in Indonesia. Overall heterosexual transmission is the main mode of transmission that dominates new case findings (69.6\%) in 2017. Cumulative frequency of HIV/AIDS is 810 cases in Central Kalimantan. Housewives (19.4\%) were the highest group after the private group. The purpose of this study was to look at the psychological determinants of housewives living with HIV (+) in Central Kalimantan Province. The method of this study was an observational analytic cross sectional study. The population is patients who visit RSUD dr. Sylvanus Palangka Raya, RSUD dr. Murjani Sampit, Sultan Immanudin Pangkalanbun Hospital and RSUD Dr.H Soemarno S Kuala Kapuas. Samples are excluded if there are psychiatric disorders and death sickness. The results showed that sociodemographic variables such as age, marriage history, ethnicity, education level, employment status, number of children, length of diagnosis and phase of HIV were not the psychological determinants of the respondents $(p>0.05)$.

Keyword: HIV AIDS, PLWHA, Quality of Psychology

\section{PENDAHULUAN}

Human Immunodeficiency Virus (HIV) telah menginfeksi dan membunuh jutaan orang secara global dalam 4 (empat) dekade terakhir, dimana prevalensi tertinggi dilaporkan di Sub-Sahara Afrika (SSA) (World Health Organization, 2011). Perempuan merupakan kelompok yang menanggung beban HIV/ AIDS lebih tinggi dari pada laki-laki di dunia maupun di negara-negara yang paling maju, karena berbagai alasan biologis, sosial, dan ekonomi. Misalnya di wilayah Sub-Sahara, aspek gender memberikan pengaruh yang besar terhadap infeksi HIV yang mana proporsi tertinggi merupakan kelompok perempuandimana di antara wanita muda berusia 1524 tahun, ada sekitar 380.000 infeksi HIV baru setiap tahun; dan $15 \%$ wanita yang hidup dengan HIV berusia 15-24 tahun, di antaranya $80 \%$ tinggal di SSA (World Health Organization, 2011).

Indonesia adalah salah satu negara berkembang yang paling terkena dampak oleh HIV. Pada tahun 2017, diperkirakan ada 630.000 orang yang hidup 
dengan HIV di negara ini $^{2}$. Jumlah infeksi HIV tertinggi yaitu di DKI Jakarta (51.981) diikuti Jawa Timur (39.633) dan Papua (29.083). Presentase kumulatif AIDS tertinggi pada laki-laki (57\%) dan perempuan 33\%). Seperti negara-negara berkembang lainnya perempuan di Indonesia juga secara tidak proporsional terpengaruh dibandingkan laki-laki. Dimana berdasarkan pekerjaan/ status adalah ibu rumah tangga (14.721) diikuti tenaga non professional/ karyawan (14.116). Secara keseluruhan penularan heteroseksual menjadi moda penularan utama yang mendominasi temuan kasus baru (69.6\%) sampai dengan kuartal ke pertama tahun 2017. Di Provinsi Kalimantan Tengah dilaporkan jumlah kumulatif HIV/AIDS mencapai 810 kasus, dimana ibu rumah tangga (19.4\%) merupakan kelompok tertinggi setelah kelompok swasta (Kemenkes RI, 2018).

Sebagai tanggapan terhadap pandemi HIV, berbagai intervensi telah dilaksanakan dengan menargetkan perbaikan metode diagnosis, rejimen pengobatan, dan memperkuat program pencegahan dan pengendalian HIV. Salah satu intervensi adalah penyediaan terapi antiretroviral (ART) kepada orangorang yang hidup dengan HIV/ AIDS (Komsi Penanggulangan AIDS Republik Indonesia, 2015). Pengobatan telah mengakibatkan penurunan kejadian penyakit dan peningkatan umur panjang dari orang yang hidup dengan infeksi (Unzila et al., 2016). Terapi antiretroviral juga meningkatkan kualitas hidup yang berhubungan dengan kesehatan (HRQoL) dari individu yang menerima pengobatan (Bor et al., 2013). Namun, beban psikologis dan ekonomi akibat infeksi HIV/AIDS dengan kronisititas yang buruk membuat manfaat HRQoL diragukan sebagai perawatan penderita dalam jangka panjang (Deeks et al., 2013; Oguntibeju, 2012).

Penelitian menunjukkan bahwa wanita dengan HIV/AIDS memiliki kualitas hidup yang buruk daripada rekan pria mereka meskipun mereka umumnya lebih patuh terhadap ART dan stadium penyakit yang serupa (Basavaraj et al., 2010; Tesfay et al., 2015; Rachmawati, 2016). Realitas ibu rumah tangga dengan HIV (+) merupakan trend baru dalam epidemi HIV/AIDS, dimana transmisi penyakit sudah bergerser ke populasi risiko rendah seperti ibu rumah tangga dan anak. Dalam hal ini HIV/AIDS bagi ibu rumah tangga merupakan beban ganda karena perannya sebagai ibu dan istri. Ibu rumah tangga dengan HIV (+) pada umumnya merupakan kelompok usia produktif dan seksual aktif sehingga infeksi HIV pada ibu rumah tangga akan meningkatkan risiko penularan HIV dari ibu ke anak saat kehamilan maupun persalinan. Selain itu infeksi HIV akan mempengaruhi hubungan perkawinan dalam sebuah rumah tangga, pada umumnya perempuan dengan HIV (+) kecenderungan akan ditinggalkan oleh suaminya karena stigma negatif yang melekat pada penderita HIV.

Infeksi HIV selain mempengaruhi kesehatan fisik juga mempengaruhi kualitas psikologis ibu rumah tangga karena kecemasan dan depresi yang pada akhirnya akan berkaitan dengan perawatan/ pengobatan dan mortalitas penderita. Penelitian Rachmawati menunjukan bahwa rata-rata kualitas psikologis ODHA rendah karena pada umumnya ODHA kurang mendapat dukungan sosial dan dukungan keluarga akibat adanya stigma dan diskriminasi sosial (Lubis et al., 2016). Penelitian Lubis variabel depresi adalah faktor yang paling berpengaruh terhadap kualitas hidup pasien HIV/ AIDS ( $\mathrm{p}=0.59$ ), dimana semakin tinggi depresi ODHA maka kualitas hidupnya semakin rendah (MaughanBrown, 2007). Penelitian Maughan-Brown, dampak HIV/ AIDS pada perempuan sangat akut terutama di afrika, perempuan sering kurang beruntung dalam ekonomi, budaya dan sosial demikian juga terhadap akses pengobatan, dukungan keuangan dan pendidikan (Weldsilase et al., 2018).

Oleh karena itu perawatan dan pengendalian HIV sudah harus memperhatikan kualitas psikologi penderita untuk mendorong kepatuhan pengobatan, kepercayaan diri, kemandirian dan perbaikan kualitas hidup penderita secara keseluruhan. Tujuan penelitian ini adalah mendeskripsikan determinan psikologi ibu rumah tangga dengan HIV (+) di Provinsi Kalimantan Tengah. Manfaat penelitian diharapkan dapat memberikan informasi kepada instansi terkait guna peningkatkan kualitas psikologi responden dalam penatalaksanaan pengendalian HIV/ AIDS baik di Provinsi Kalimantan Tengah secara khusus dan di Indonesia pada umumnya. 


\section{METODE PENELITIAN}

Penelitian ini menggunakan metode observasional analitik dengan pendekatan cross sectional study (studi potong lintang). Populasi adalah ibu rumah tangga dengan HIV (+) di Provinsi Kalimantan Tengah, sedangkan sampel adalah subyek yang berkunjung ke klinik VCT RSUD dr. Doris Sylvanus Palangka Raya, RSUD dr.Murjani Sampit, RSUD Sultan Immanudin Pangkalanbun dan RSUD dr.H Soemarno Kuala Kapuas. Penarikan sample menggunakan metode purposive sampling dengan kriteria responden dengan nilai CD4 > $200 \mathrm{sel} / \mu \mathrm{L}$ dan bersedia mengisi informed consent. Sample diekluasi apabila mengalami gangguan kejiwaan dan atau sakratul maut.Penelitian memenuhi kalaikan etik dari Komisi Etik Fakultas Kedokteran Universitas Lambung Mangkurat No.955/KEPK-FKUNLAM/EC/X/2018.

Jumlah populasi studi dalam penelitian ini ditentukan menggunakan rumus uji hipotesis 2 populasi, sehingga diperoleh besar sample 53 responden. Pada awal penelitian, tim memberi penjelasan tentang tujuan dan prosedur penelitian, kemudian subyek diminta mengisi informed consent, dan dilakukan pengecekkan nilai CD4. Apabila memenuhi persyaratan maka subyek diikutkan dalam penelitian, sehingga jumlah subyek yang terkumpul sebanyak 57 orang. Pada tahap selanjutnya responden diminta mengisi koesinoer sesuai dengan petunjuk yang diberikan dan apabila responden tidak dapat membaca maka akan didampingi oleh tim.

Pengumpulan data kualitas psikologi responden menggunakan instrument WHOQOL BRIEF yang telah tervalidasi.Dalam penelitian ini turut dikumpulkan beberapa data antara lain usia, tingkat pendidikan, pekerjaan, status perkawinan, jumlah anak, lama menderita HIV, jenis pengobatan yang diperoleh, dukungan keluarga, pemanfaatan layanan kesehatan dan keikutsertaan dalam kelompok dukungan sebaya. Data diolah menggunakan SPSS versi 17.0 dan dianalisis menggunakan secara univariat, bivariate menggunakan uji chi square, dimana variabel yang memiliki nilai $\mathrm{p}<0.25$ akan diikutkandalam analisis multivariate dengan menggunakan uji regresi logistik. Variabel dikatakan berhubungan signifikan jika $p$ value $<0.05$.

\section{HASIL DAN PEMBAHASAN}

Tabel 1 menunjukan bahwa rerata responden berusia 37 tahun, dimana mayoritas $<37$ tahun $(52.6 \%)$, tidak bekerja (68.4\%), tingkat pendidikan rendah $(54.4 \%)$, janda $(32.7 \%)$, dengan pekerjaan suami/ mantan pasangan sebagian besar adalah karyawan swasta (57.9\%) diikuti tenaga honorer (22.8\%). Berdasarkan jumlah anak sebagian besar responden memiliki 1-3 anak (47.4\%), pendatang (54.4\%), lama terdiagnosa $\geq 3$ tahun (56.1\%), bergejala AIDS (36.8\%) dan $59.6 \%$ telah menerima ARV.

TABEL 1. Karakteristik Responden

\begin{tabular}{|c|c|c|}
\hline \multirow[b]{2}{*}{ Karakteristik } & \multicolumn{2}{|c|}{ Frekuensi } \\
\hline & $\begin{array}{c}\text { Jumlah } \\
\mathrm{N}=57\end{array}$ & $\begin{array}{c}\text { Persentase } \\
(\%)\end{array}$ \\
\hline \multicolumn{3}{|l|}{ Usia(Tahun) } \\
\hline$<37$ & 30 & 52.6 \\
\hline$\geq 37$ & 27 & 47.4 \\
\hline \multicolumn{3}{|l|}{ Pekerjaan Responden } \\
\hline Tidak Bekerja & 39 & 68.4 \\
\hline Bekerja & 18 & 31.6 \\
\hline \multicolumn{3}{|l|}{ Tingkat Pendidikan } \\
\hline Rendah & 31 & 54.4 \\
\hline Tinggi & 26 & 45.6 \\
\hline \multicolumn{3}{|l|}{ Status Pernikahan } \\
\hline Janda & 18 & 32.7 \\
\hline Kawin & 39 & 67.3 \\
\hline \multicolumn{3}{|l|}{ Pekerjaan Suami/ Mantan } \\
\hline ASN/ TNI/POLRI & 3 & 5.3 \\
\hline Karyawan Swasta & 33 & 57.9 \\
\hline Pedagang & 1 & 1.8 \\
\hline Supir Angkot/ Truk & 1 & 1.8 \\
\hline Buruh Bangunan/ Pabrik & 1 & 1.8 \\
\hline Petani/ Nelayan & 4 & 7.0 \\
\hline Honorer & 13 & 22.8 \\
\hline Lainnya & 1 & 1.8 \\
\hline \multicolumn{3}{|l|}{ Jumlah Anak } \\
\hline$>3$ orang & 20 & 35.1 \\
\hline $1-3$ orang & 27 & 47.4 \\
\hline 0 & 10 & 17.5 \\
\hline \multicolumn{3}{|l|}{ Suku } \\
\hline Pendatang & 31 & 54.4 \\
\hline Pribumi & 26 & 45.6 \\
\hline \multicolumn{3}{|l|}{ Lama Terdiagnosa HIV } \\
\hline$\geq 3$ tahun & 32 & 56.1 \\
\hline$<3$ tahun & 25 & 43.9 \\
\hline \multicolumn{3}{|l|}{ Pendekatan Diagnosa } \\
\hline Sukarela & 20 & 35.1 \\
\hline Inisiatif Petugas Kesehatan & 37 & 64.9 \\
\hline \multirow[b]{2}{*}{ Karakteristik } & \multicolumn{2}{|c|}{ Frekuensi } \\
\hline & $\begin{array}{c}\text { Jumlah } \\
\mathrm{N}=57\end{array}$ & $\begin{array}{c}\text { Persentase } \\
(\%)\end{array}$ \\
\hline
\end{tabular}




\begin{tabular}{lcc}
\hline Fase & & \\
Bergejala AIDS & 21 & 36.8 \\
Tidak Bergejala & 36 & 63.2 \\
\hline Terapi Yang Diperoleh & 4 & \\
Vaksinasi & 34 & 5.0 \\
ARV & 3 & 5.3 \\
Profilaksis & 16 & 28.1 \\
Menerima lebih dari 1 terapi & \\
\hline
\end{tabular}

TABEL 2. Kualitas Psikologi Ibu Rumah Tangga dengan HIV (+) di Provinsi Kalimantan Tengah Tahun 2018

\begin{tabular}{lcc}
\hline \multirow{2}{*}{ Kualitas Psikologi } & \multicolumn{2}{c}{$\begin{array}{c}\text { Frekuensi } \\
\mathrm{n}=57\end{array}$} \\
\cline { 2 - 3 } & Jumlah (n) & Presentase (\%) \\
\hline Buruk & 35 & 61.4 \\
Baik & 22 & 38.6 \\
Mean \pm SD & \multicolumn{2}{c}{$13.41 \pm 2.31$} \\
\hline
\end{tabular}

Tabel 2 menunjukan bahwa sebagian besar responden memiliki kualitas psikologi yang buruk (61.4\%) pada rentang $13.41 \pm 2.31$ (skor yang dimungkinkan ; 4-20) .

TABEL 3. Determinan Kualitas Psikologi Ibu Rumah Tangga dengan HIV (+) di Provinsi Kalimantan Tengah Tahun 2018

\begin{tabular}{|c|c|c|c|c|c|}
\hline \multirow[t]{2}{*}{ Kualitas Hidup } & \multicolumn{2}{|c|}{$\begin{array}{c}\text { Kualitas Psikologi } \\
\mathrm{N}=57\end{array}$} & \multirow{2}{*}{$\begin{array}{c}\text { Uji } \\
\text { Bivariat }\end{array}$} & \multirow{2}{*}{$\begin{array}{c}\text { Uji } \\
\text { Multivariat }\end{array}$} & \multirow{2}{*}{$\begin{array}{c}95 \% \text { CI } \\
\text { Lower-upper }\end{array}$} \\
\hline & Buruk & Baik & & & \\
\hline \multicolumn{6}{|l|}{ Usia } \\
\hline$>37$ tahun & $18(51.4 \%)$ & $12(54.5 \%)$ & \multirow[t]{2}{*}{0.053} & \multirow[t]{2}{*}{0.697} & \multirow[t]{2}{*}{$0.241-2.589$} \\
\hline$<37$ tahun & $17(48.6 \%)$ & $10(45.5 \%)$ & & & \\
\hline \multicolumn{6}{|l|}{ Pekerjaan } \\
\hline Tidak Bekerja & $25(71.4 \%)$ & $14(63.6 \%)$ & \multirow[t]{2}{*}{0.38} & \multirow[t]{2}{*}{-} & \multirow[t]{2}{*}{$0.458-4.453$} \\
\hline Bekerja & $10(28.6 \%)$ & $8(36.4 \%)$ & & & \\
\hline \multicolumn{6}{|l|}{ Status Pendidikan } \\
\hline Rendah & $20(57.1 \%)$ & $11(50.0 \%)$ & \multirow[t]{2}{*}{0.278} & \multirow[t]{2}{*}{0.560} & \multirow[t]{2}{*}{$0.464-4.118$} \\
\hline Tinggi & $15(42.9 \%)$ & $11(50.0 \%)$ & & & \\
\hline \multicolumn{6}{|l|}{ Status Perkawinan } \\
\hline Cerai & $11(31.4 \%)$ & $7(31.8 \%)$ & \multirow[t]{2}{*}{0.001} & \multirow[t]{2}{*}{0.908} & \multirow[t]{2}{*}{$0.255-3.362$} \\
\hline Kawin & $24(68.6 \%)$ & $15(68.2 \%)$ & & & \\
\hline \multicolumn{6}{|l|}{ Jumlah Anak } \\
\hline$>3$ orang & $5(14.2 \%)$ & $4(18.2 \%)$ & \multirow[t]{3}{*}{-} & \multirow[t]{3}{*}{2.041} & \multirow[t]{3}{*}{-} \\
\hline $1-3$ orang & $21(60.0 \%)$ & $16(72.7 \%)$ & & & \\
\hline 0 orang & $9(25.7 \%)$ & $2(9.1 \%)$ & & & \\
\hline \multicolumn{6}{|l|}{ Suku } \\
\hline Pendatang & $20(57.1 \%)$ & $11(50.0 \%)$ & \multirow[t]{2}{*}{1.333} & \multirow[t]{2}{*}{-} & \multirow[t]{2}{*}{$0.457-3.890$} \\
\hline Pribumi & $15(42.9 \%)$ & $11(50.0 \%)$ & & & \\
\hline \multicolumn{6}{|l|}{ Lama Didiagnosa HIV } \\
\hline$>3$ tahun & $20(57.1 \%)$ & $12(54.5 \%)$ & \multirow[t]{2}{*}{0.900} & \multirow[t]{2}{*}{-} & \multirow[t]{2}{*}{$0.308-2.633$} \\
\hline$\leq 3$ tahun & $15(42.9 \%)$ & $10(45.5 \%)$ & & & \\
\hline Gejala HIV & & & & & \\
\hline Bergejala AIDS & $16(45.7 \%)$ & $5(22.7 \%)$ & 3.068 & - & $0.864-9.492$ \\
\hline Tidak Bergejala & $19(54.3 \%)$ & $17(77.3 \%)$ & & & \\
\hline
\end{tabular}


Tabel 3 menunjukan bahwa variabel yang lolos dalam uji bivariate adalah usia $(\mathrm{p}=0.053)$, pendidikan $(\mathrm{p}=0.278)$, status pernikahan $(\mathrm{p}=0.001)$ dan jumlah anak ( $\mathrm{p}=0.026$ ). Hasil uji statistik pada uji multivariat menunjukan bahwa tidak ada hubungan usia, status pendidikan, status perkawinanan dan jumlah anak ( $\mathrm{p}$ > 0.05) terhadap kualitas psikologi responden.

Hasil penelitian menunjukan bahwa sebagian besar responden memiliki kualitas psikologis yang buruk (61.4\%), yang mana prevelensilebih tinggi pada responden yang berusia > 37 tahun $(51.4 \%)$, tidak bekerja (71.4\%), pendidikan rendah $(57.1 \%)$, berstatus menikah (68.6\%), mempunyai anak 1-3 orang $(60.1 \%)$, suku pendatang $(57.1 \%)$, lama menderita HIV > 3 tahun (57.1\%) dan belum mengalami gejala AIDS (54.3\%).Namun demikian hasil uji statistik menunjukan bahwa usia, status pekerjaan, tingkat pendidikan, status perkawinan, jumlah anak, suku, lama didiagnosa dan fase HIV tidak mempunyai hubungan dengan kualitas psikologis responden.

Sejalan dengan penelitian Weldsilase et al (2018) bahwa usia, tempat tinggal, pendidikan, perkawinan dan status pekerjaan tidak memiliki hubungan dengan kualitas hidup wanita dengan HIV/ AIDS termasuk kualitas psikologi. Namun durasi penggunaan ART mempunyai hubungan signifikan dengan kualitas hidup secara keseluruhan, dimana durasi penggunaan ART yang lebih pendek memiliki kualitas hidup yang lebih baik (Monteiro et al., 2017). Dalam penelitian ini mayoritas responden telah didiagnosa HIV $\geq 3$ tahun dan mengkonsumsi ART sejak didiagnosa HIV, yang mana sebagian besar memiliki kualitas psikologi yang buruk. Hal ini menguatkan fakta bahwa HIV/ AIDS adalah satu penyakit kronis yang mempengaruhi aspek ekonomi, psikologis dan sosial pasien sehingga penggunaan ART kerapkali tidak bisa menghentikan laju pogresifitas penyakit.

Penelitian Monteiro et al (2017) bahwa tidak ada perbedaan tekanan psikologis pada wanita lebih muda dan wanita yang tua, namun ada dugaan bahwa tekanan psikologis diakibatkan oleh riwayat transmisi HIV dari penggunaan IDU, sehingga ada korelasi terhadap obat atau zat yang digunakan sebelumnya terhadap kondisi psikologis penderita. Selain itu ditemukan bukti bahwa adanya koinfeksi tekanan psikologi pada wanita yang lebih muda disebabkan karena menderita penyakit Hepatitis C. Hal ini perlu diperhatikan karena adanya bukti hubungan postif antara tekanan psikologis dan kehadiran HIV dalam kombinasi dengan infeksi lain terutama Hepatitis C (Catz et al., 2002). Dalam penelitian ini kita tidak mempunyai bukti tentang riwayat penggunaan IDU oleh responden sehingga belum bisa dikatakan apakah penurunan kualitas psikologi responden berhubungan positif dengan penggunaan obat-obat terlarang. Begitupula dengan adanya koinfeksi antara HIV dan infeksi penyakit lainnya. Sejauh ini penelitian masih terbatas pada tahap menilai adanya gejala AIDS atau tanpa gejala, dimana ditemukan fakta bahwa sebagian besar responden yang mengalami penurunan kualitas psikologi adalah mereka dengan HIV (+) tanpa gejala AIDS (54.3\%). Hal ini dimungkinkan karena adanya ketakutan atau tekanan dalam diri responden terhadap prognosa penyakit yang akan dihadapi pada masa yang akan datang.

Beberapa penelitian juga membuktikan bahwa HIV/AIDS adalah sindrom klinis yang berdampak pada hilangnya progresifitas fisik, kelelahan, gangguan pernapasan dan berbagai infeksi oppurtunistik lainnya sehingga penyakit ini membatasi kegiatan sosial dan harian perempuan dan dapat menimbulkan tekanan emosional dan gangguan kualitas psikologis (Gielen et al., 2001; Dinkes Provinsi Kalteng, 2016). Pada umumnya tingkat kecemasan yang tinggi dan depresi yang dialami oleh orang dengan HIV/AIDS dikaitkan dengan ketidakpatuhan terhadap regimen pengobatan, percepatan perkembangan penyakit dan penurunan kualitas fisik, dan rendahnya harapan hidup (Holzemer et al., 1999; Leserman et al., 1999; Lyon \& Younger, 2001; Schonnesson, 2002). Selain itu terdapat faktor sosial seperti diskriminasi sosial, isolasi, dan keterbatasan dalam perawatan/ pengobatan juga dihadapioleh banyak ibu terinfeksi HIV bahkan membuat merekalebih rentan terhadap penurunan kualitas psikologis (WHO dan Kemenkes RI, 2017).

Dalam penelitian ini ibu rumah tangga dengan HIV (+) cenderung dirugikan karena kemiskinan akibat tidak bekerja dan pendidikan yang rendah. 
Selain itu responden juga sangat terbatas dalam memilih atau melakukan perawatan yang tepat bagi kondisi kesehatannya akibat kurangnya biaya dan rendahnya dukungan keluarga untuk mengakses pengobatan. Di sisi lain penyakit ini cenderung menghambat mereka untuk melakukan aktivitas karena kondisi fisik yang kerapkali mengalami gejala sakit atau infeksi dan adanya stigma negative terhadap penderita HIVAIDS. Kondisi-kondisi tersebut kerapkali membuat responden merasa cemas, putus asa, ingin bunuh diri, depresi dan pada akhirnya memperburuk kondisi psikologis mereka .

Kendati demikian layanan kesehatan fisik dan psikologi telah tersedia namun keberadaannya masih minim. Pada Tahun 2018 terdapat 4 (empat) klinik VCT yang tersebar di daerah endemis HIV/ AIDS yaitu Kota Palangka Raya (RSUD dr. Doris Sylvanus), Kabupaten Kotawaringin Timur (RSUD dr. Murani Sampit), Kabupaten Kapuas ( RSUD dr.H.Soemarno S Kuala Kapuas) dan Kabupaten Kotawaringin Barat (RSUD Sultan Imanuddin Pangkalanbun) (Shamos et al., 2009). Dalam implementasinya penatalaksaan konseling HIV pada kelompok penderita dinilai masih pasif belum sepenuhnya dapat menjangkau semua kelompok karena rendahnya peran pemerintah daerah dalam pengendalian HIV/ AIDS. Hal ini sehingga diduga merupakan faktor pemungkin dalam penurunan kualitas psikologis responden. Sejalan dengan laporan kajian nasional penanggulangan HIV di Indonesia pada Tahun 2017, yang mana diakui bahwa proses desentralisasi telah menciptakan peluang untuk memperluas respon HIV, namun ketidakjelasan peran para aktor di tiap tingkatan pemerintahan dan tidak selarasnya kebijakan hukum, pratik penganggaran, perencanaan strategis dan implementasi antara tingkat pusat dan daerah memicu fragmentasi yang menghambat efektifitas dan efisiensi respon (Widayati, 2016).

Faktor lain dalam mendeskripsikan psikologis perempuan dengan HIV/ AIDS adalah adanya stigma dan dukungan sosial. Penelitian Shamos et al. (2009) menemukan bahwa stigma dan diskriminasi sosial sangat kental terjadi pada kelompok perempuan dari pada laki-laki. Hal tersebut cenderung memperburuk kualitas psikologis perempuan ditambahlagi adanya masalah ekonomi yang tidak pasti dan emosional yang tidak stabil (Shamos et al., 2009). Hasil penelitian kami menunjukkan bahwa sebagian besar responden masih merahasiakan statusnya terhadap keluarga maupun lingkungan sosialnya karena adanya stigma dan diskriminasi sosial dalam masyarakat, akibatnya secara emosional responden tidak mempunyai teman dekat untuk berbagi keluh kesah tentang penyakit yang diderita. Kondisi tersebut membuat responden menghindari keterbukaan dan tidak mencari bantuan dari orang lain sehingga meningkatkan kecemasan, isolosi dan rasa kesepian yang berdampak pada penurunan terhadap kondisi psikologis responden.

Disisi lain isolasi dan ketidakterbukaan ODHA merupakan ancaman yang serius bagi epidemi HIV sehingga kami menyarankan bahwa, di samping meningkatkan perawatan kesehatan, upaya yang ditujukan untuk mengurangi diskriminasi dan mengubah persepsi umum terhadap orang dengan HIV/AIDS harus ditingkatkan. Penelitian Nur Widayati, Murtaqib (2016) menunjukan bahwa pentingnya memasukan aspek psikososial dalam pengembangan model rehabilitasi klien HIV/ AIDS antara lain dengan penyediaan fasilitas konseling psikologis, self help group, sosial support group dan pelibatan peran keluarga (Shamos et al., 2009).

Variabel lain yang tidak dikumpulkan, seperti riwayat IDU, beban keuangan, tingkat kepatuhan dalam pengobatan ARV, status kesuburan dan menopause perlu dilanjutkan sebagai masukan yang signifikan dalam penelitian kami. Penilaian variabelvariabel ini mungkin relevan untuk memperjelas faktor dan/atau mekanisme yang mendasari determinan psikologis ibu rumah tangga dengan HIV (+). Terlepas dari keterbatasan ini, penelitian ini memiliki kekuatan yang penting. Studi ini menunjukkan bahwa tekanan psikologis pada kelompok ibu rumah tangga dengan HIV (+) tidak berhubungan dengan sosiodemografi namun terdapat faktor-faktor lain sebagai pemungkin yang harus dipertimbangkan dalam penanganan kesehatan mental pada penderita HIV.

\section{KESIMPULAN}

Sebagai kesimpulan penelitian kami bahwa sosio demografi seperti usia, status perkawinan, 
ttingkat pendidikan, status pekerjaan, jumlah anak, lama didiagnosis HIV dan fase HIV bukan merupakan determinan psikologis ibu rumah tangga dengan HIV (+) di Provinsi Kalimantan Tengah, namun perlu dipertimbangkan faktor lain seperti riwayat penggunaan IDU, koninfeksi dengan penyakit lain, rendahya kegiatan konseling dan rendahnya dukungan sosial/ keluarga. Dalam hal ini, diperlukan model komprehensif dalam penatalaksanaan HIV/ AIDS dimana perawatan kesehatan fisik senantisa diintegrasikan dengan pendampingan psikologis, kemandirian ODHA serta upaya meminimalisir stigma yang berkembang dalam masyarakat.

\section{DAFTAR PUSTAKA}

Basavaraj, K. H., Navya, M. A., and Rashmi, R. 2010. Quality of life in HIV/AIDS. Indian Journal of Sexually Transmitted Diseases and AIDS. 31 (2) : 75-80.

Bor, J., Herbst, A. J., Newell, M.-L., and Bärnighausen, T. 2013. Increases in adult life expectancy in rural South Africa: Valuing the scale-up of HIV treatment. Science. 339 (6122) : 961-965.

Catz, S. L., Gore-Felton, C., and McClure, J. B. 2002. Psychological distress among minority and lowincome women living with HIV. Behavioral Medicine. 28 : 53-60.

Deeks, S. G., Lewin, S. R., and Havlir, D. V. 2013. The end of AIDS: HIV infection as a chronic disease. The Lancet. 382 (9903) : 1525-1533.

Dinas Kesehatan Provinsi Kalimantan Tengah. Profil Kesehatan Provinsi Kalimantan Tengah. 2016.

Gielen, A. C., McDonnell, K. A., Wu, A. W., O'Campo, P., and Faden, R. 2001. Quality of life among women living with HIV: The importance of violence, social support, and self care behaviors. Social Science and Medicine. 52 :315-322.

Kesehatan Republik Indonesia. 2018. Situasi HIV dan IMS di Indonesia hingga Maret 2017. Pusdatin Kementerian Kesehatan RI.
Komisi Penanggulangan AIDS Republik Indonesia. 2015. Strategi dan Rencana Aksi Nasional 2015-2019. Penanggulangan AIDS di Indonesia.

Lubis, Lisnawati, Sarumpeat, S.M., and Ismayadi. 2016. Hubungan Stigma, Depresi dan Kelelahan terhadap Kualitas Hidup Pasien HIV/ AIDS di Klinik Veteran Medan. Idea Nursing Journal. 7 (1) : 1-12.

Maughan-Brown, B. 2007. Experiences and perception of HIV/ AIDS-related stigma among people on antiretroviral treatment in Khayelistha South Africa, Centre for social science research (CSSR) working Paper No.185 March 2007.

Monteiro, F., Canavarro, M. C., and Pereira, M. 2017. Prevalence and correlates of psychological distress among middle-aged and older women living with HIV. Psychology, Health \& Medicine. 22 (9) : 1105-1117.

Oguntibeju, O. O. Quality of Life of People Living with HIV and AIDS and Antiretroviral Therapy. 2012. HIV/AIDS-Research and Palliative Care. $4: 117-124$.

Rachmawati dan Suhardiana. 2016. Kualitas Hidup Orang dengan HIV/ AIDS yang mengikuti terapi antiretroviral. Jurnal Sains dan Praktik Psikologi. 1(1).

Shamos, S., Hartwig, K. A., and Zindela, N. 2009. Men's and women's experiences with HIV and stigma in Swaziland. Sage Journals. 19 (12).

Shamos, S., Hartwig, K. A., and Zindela, N. 2009. Men's and women's experiences with HIV and stigma in Swaziland. Qual Health Res. 19 : 1678-1689.

Tesfay, A., Gebremariam, A., Gerbaba , M., and Abrha, H. 2015. Gender Differences in Health Related Quality of Life among People Living with HIV on Highly Active Antiretroviral Therapy in Mekelle Town, Northern Ethiopia. BioMed Research International.

Unzila, S. R., Nadhiroh, S. R., and Triyono, E. A. 2016. Hubungan kepatuhan antiretroviral 
(ART) satu bulan terakhir dengan kualitas hidup pasien HIV/ AIDS di RSUD Dr. Sutomo Surabaya. Media Gizi Indonesia. 11 (1) : 23-31.

Weldsilase, Y. A., Melaku H. L., Tolossa, W., and Mulusew, G. 2018. Health-Related Quality of Life and Associated Factors among Women on Antiretroviral Therapy in Health Facilities of Jimma Town, Southwest Ethiopia. Hindawi Advances in Public Health. 1-12.

Widayati, N. 2016. Identifikasi Status Psikologi sebagai upaya pengembangan model rehabilitasi klien HIV / AIDS berbasis komunitas. Nurseline Journal. 1 (1) : 90-99.

World Health Organization (WHO). 2011. Global HIV/AIDS Response - Epidemic update and health sector progress towards Universal Access: Progress Report, WHO, Geneva, Switzerland.

World Health Organization dan Kementerian Kesehatan Republik Indonesia. Kajian Nasional Respon HIV di bidang Kesehatan Republik Indonesia. Laporan tahun 2017 